\title{
EFFECT OF GINGER AND ROSEMARY EXTRACTS AS ANTIOXIDANT AND ANTIBACTERIAL AGENTS IN TILAPIA FISH FINGERS
}

\author{
DEISE CAROLINE BIASSI ${ }^{1}$ \\ LARISSA SCHLICHTING DA SILVA ${ }^{2}$ \\ LARISSA ALVES DELFINO ${ }^{3}$ \\ JAQUELINE DE OLIVEIRA ${ }^{4}$ \\ LUCIANO TORMEN ${ }^{5}$ \\ EDUARDA MOLARDI BAINY ${ }^{6}$
}

\begin{abstract}
This work aimed to evaluate the antioxidant and antibacterial effects of commercial ginger and rosemary extracts on tilapia fish fingers during frozen storage. Three formulations of fish fingers using tilapia mechanically separated meat (MSM) were produced with $2.5 \%$ of hydroalcoholic ginger extract (GE), $2.5 \%$ of oily rosemary extract (RE) and a control. pH, instrumental color, peroxide value (PV), determination of thiobarbituric acid reactive substances (TBARS), and sensorial evaluation with a trained panel, were carried out monthly during 120 days of frozen storage. Total mesophilic and Enterobacteriaceaecounts were conducted at the beginning and the end of storage. pH remainednear 6.0. GE showed a darker color (lower $L^{*}$ ) at the end of the study. PV reduced with storage time, however, there was no difference among formulations. RE had the lowest TBARS value at 120 days. GE became with an unacceptable flavor and had the highest TBARS value at the end of frozen storage. There was a little reduction in the bacteria counts for the products with extracts. Rosemary extract was more efficient in reducing the lipid oxidation of frozen fish fingersthan ginger extract.
\end{abstract}

KEYWORDS: NATURAL EXTRACTS; ZINGIBER OFFICINALE; ROSMARINUS OFFICINALIS; LIPID OXIDATION; SHELF LIFE

1 Food Engineering Undergraduate student, Federal University of FronteiraSul- Campus Laranjeiras do Sul. E-mail: deisebiassi@hotmail.com

2 Food Engineering Undergraduate student, Federal University of FronteiraSul - Campus Laranjeiras do Sul. E-mail: larischs@hotmail.com

3 Food Engineering Undergraduate student, Federal University of FronteiraSul - Campus Laranjeiras do Sul. E-mail: adlaarissa@gmail.com

4 Food Engineering Undergraduate student, Federal University of FronteiraSul - Campus Laranjeiras do Sul. E-mail: jaquelineoliveira1995@hotmail.com

5 Doctor in Chemistry, Food Engineering Professor, Federal University of FronteiraSul - Campus Laranjeiras do Sul. E-mail: luciano.tormen@uffs.edu.br

6 Doctor in Food Engineering, Food Engineering Professor, Federal University of FronteiraSul - Campus Laranjeiras do Sul. E-mail: eduarda.bainy@uffs.edu.br 


\section{INTRODUCTION}

Approximately one-third of the food produced annually for human consumption in the world is lost or wasted, which accounts for about 1.3 billion tons of food (FAO, 2011). Fish wasterepresents a valuable source of proteins, minerals and other nutrients (MUZZOLON et al., 2018) and can contribute to food security.

Fish is highly perishable due to high water activity and nutrient availability, as well as, the presence of free amino acids, polyunsaturated fatty acids, autolytic enzymes and $\mathrm{pH}$ close to neutrality (SOARES et al., 2014).Biological reactions, such as lipid oxidation, enzymatic activity and metabolic activity of microorganisms, resulting in rapid fish deterioration, are usually responsible for the loss of product freshness (ARASHISAR et al., 2004). Antioxidants and antimicrobials are usually added in fish products to retard the lipid oxidation and microbial development, respectively. These ingredients can be derived from natural and synthetic sources.

Synthetic additives have been associated with adverse health effects, such as allergies, hyperactivity (POLONIO; PERES, 2009) and cancer development (BOTTERWECK, et al. 2000). As a result, the food industry is looking to substitute synthetic additives with naturalsubstancesdue to consumer trends (CAROCHO; MORALES; FERREIRA, 2018). Rosemary extract is a natural ingredient and contains a significant quantity of the phenolic diterpenes, carnosic acid andcarnosol, which have antioxidant potential in foods (FRANKEL, 1999). The main constituents of rosemary essential oil-rich fractionobtained by supercritical $\mathrm{CO}_{2}$ extraction werea-pinene, 1,8-cineole, camphor, verbenone, and borneol (SANTOYO et al., 2005). Angioni et al. (2004) also identified these compounds in essential oil extracted by the hydro distillation method. Moreover, the essential oil has antimicrobial properties reported in the literature (PORTE; GODOY, 2001). A previous study found antimicrobial activity against gram-positive bacteria (Staphylococcus aureusand Bacillus subtilis), gram-negative bacteria (Escherichia coli and Pseudomonas aeruginosa), a yeast (Candida albicans), and a fungus (Aspergillus niger) (SANTOYO et al., 2005).

Another natural food preservative is the ginger extract which has antioxidant (MISHARINA; TERENINA; KRIKUNOVA, 2009; MESOMO et al., 2012) and antimicrobial (SIVASOTHY et al., 2011; PISOSCHI et al., 2018) properties described in the literature. Essential oil and supercritical $\mathrm{CO}_{2}$ extracts of ginger has similar chemical composition; however, they contained varying amounts of the compounds (MESOMO et al., 2013). The authors identified that the major components in the $\mathrm{CO}_{2}$ extracts were $\alpha$-zingiberene, $\beta$ sesquiphellandrene, $\alpha$-farnesene, geranial, $\beta$-bisabolene and $\beta$-eudesmol. In addition, $\alpha-$ curcumene, geranial and camphene were the main compounds in the essential oil. Methanol extracts of ginger showed effective antimicrobial activity against food spoilage and food-borne pathogens, suchas, Escherichia coli, Salmonella enteriditis, Staphylococcus aureus, Bacillus cereus, among others (SUNILSON et al., 2009).

Rosemary and ginger extracts have been applied to fish and other seafood products as natural antioxidants and antimicrobials (HASSOUN; ÇOBAN, 2017). Rosemary extract prevented lipid oxidation and improved the sensory quality of sardine (OZOGUL et al., 2010). Fish fingers from Sardasarda treated with ginger essential oil extended shelf life during refrigerated storage compared to the control (ÇOBAN, 2013).

These previous studies used commercial extracts and showed promising results for fish conservation.Commercial extracts derived from natural sources are available to 
manufacturers to use them as natural preservatives. However, to the best of our knowledge, there are still limited studies on the application of natural extracts in tilapia (Oreochromisniloticus) and its products.Therefore, thisstudy aimed to evaluate the antioxidant and antibacterial effects of commercial extracts of ginger (Zingiberofficinale) and rosemary (Rosmarinusofficinalis) in tilapia fish fingers during frozen storage for 120 days.

\section{MATERIAL AND METHODS}

\subsection{PREPARATION OF FISH FINGERS}

The fish fingers were prepared with $70 \%$ of mechanically separated meat (MSM) from V-cut fillet trimmings and $30 \%$ of MSM from tilapia (Oreochromisniloticus) carcass, which are tilapia filleting residues. The MSMs were donated by Tilapia Brazilian(Toledo, PR). The remaining ingredients $(0.5 \%$ salt, $0.9 \%$ seasonings, $3 \%$ corn starch, $2.5 \%$ extracts or mineral water) were added based on the total mass of MSM. Ginger extract (GE), Rosemary extract (RE), and Control formulations had $2.5 \%$ ginger hydroalcoholic extract, $2.5 \%$ rosemary oil extract, and $2.5 \%$ water, respectively. The extract concentrations were determined by preliminary experiments to define the maximum level that did not interfere with product texture. Commercial extracts were donated by DuasRodas (Jaraguá do Sul, SC). They were stored in the dark at refrigeration temperature and used within the shelf life period defined by the company.

Ingredients were weighed in a semi-analytical balance (UX6200H, SHIMADZU, São Paulo, SP) and then homogenized in a cutter (CUT .4, METVISA, Brusque, SC) for 2 min. The mixture remained at rest at $-18^{\circ} \mathrm{C}$ for $1 \mathrm{~h}$, to facilitate the molding step. Subsequently, $20 \mathrm{~g}$ of the batter was measured and molded manually in a rectangular shape $(7 \mathrm{~cm}$ long $\times 2 \mathrm{~cm}$ wide) of stainless steel in the fish finger format. Dimensions were based on commercial product size. The strips were placed in low-density polyethylene packaging and frozen in a horizontal freezer (H500, Electrolux, Curitiba-PR), with the "quick freeze" function activated. After frozen, the samples were submitted to three breading steps: pre-dust, batter, and final breading flour (Baptistella Alimentos, Itatiba, SP). The breaded strips were placed in low-density polyethylene packagings and frozen for $12 \mathrm{~h}$ (overnight) at $-18^{\circ} \mathrm{C}$ in the same horizontal freezer.

Three batches of each formulation were produced, totaling50 products of each formulation. The samples were stored in a vertical freezer (FFE24, Electrolux, Curitiba, PR) at $-18{ }^{\circ} \mathrm{C}$ for up to 120 days. Ten samples of each formulation were randomly chosen at each sampling time.All analyses, except sensory, were performed with thawed crude samples.Samples were thawed at refrigeration temperature for $2 \mathrm{~h}$ before analysis. For sensory evaluation, the frozen fish fingers were baked in an oven (C20, Technicook Practice, Pouso Alegre, MG) preheated at $180^{\circ} \mathrm{C}$ for $10 \mathrm{~min}$, and then cooked for $10 \mathrm{~min}$, until the center reached $70^{\circ} \mathrm{C}$ monitored with a digital thermometer. The analyses were performed monthly at $0,30,60,90$ and 120 days of frozen storage. Microbiological tests were carried out at 0 and 120 days. 


\section{$2.2 \mathrm{pH}$ DETERMINATION}

The sample $(10 \mathrm{~g})$ was homogenized manually with $100 \mathrm{~mL}$ of distilled water for 2 min. The $\mathrm{pH}$ value was measured with a calibrated $\mathrm{pH}$ meter (HI2221, HANNA instruments, Tamboré, SP), as described by Instituto Adolfo Lutz (IAL, 2008). The analysis was carried out in triplicate.

\subsection{DETERMINATION OF PEROXIDE VALUE (PV)}

PV determination was performed using the fat extracted from the sample by the BlighDyer method (BLIGH; DYER, 1959). $5 \mathrm{~mL}$ of the chloroform phase was removed in a test tube and evaporated in an oven at $70^{\circ} \mathrm{C}$. After evaporation, the remaining fat was dissolved with a 2 $\mathrm{mL}$ of benzene-methanol solution. $0.2 \mathrm{~mL}$ of that solution was transferred to polypropylene tube with $10 \mu \mathrm{l}$ of $30 \%$ ammonium thiocyanate, $10 \mu \mathrm{l}$ of $10 \mathrm{mmol} / \mathrm{L}$ and benzene-methanol solution to make up to $6 \mathrm{~mL}$. The blank was prepared with benzene-methanol solution analogously. All tubes were homogenized for $15 \mathrm{~s}$ and taken to a water bath at $50^{\circ} \mathrm{C}$ for $2 \mathrm{~min}$. Subsequently, they were cooled to room temperature, and the reading was performed in a spectrophotometer (350-700 nm). Results were expressed in miliequivalent of peroxide oxygen per kilogram of fat (meq $\mathrm{O}_{2} / \mathrm{kg}$ of fat). The analysis was performed in triplicate.

\subsection{DETERMINATION OF THIOBARBITURIC ACID REACTIVE SUBSTANCES (TBARS)}

Sample $(1.0 \mathrm{~g})$ was transferred to polypropylene tube with $5.0 \mathrm{~mL}$ of $1 \%$ potassium chloride $(\mathrm{m} / \mathrm{v})$. The mixture was vortexed for $2 \mathrm{~min}$ and centrifuged for $10 \mathrm{~min}$ at $5000 \mathrm{rpm}$. A $1.0 \mathrm{~mL}$ of the supernatant aliquot was transferred to another polypropylene tube with $250 \mu \mathrm{L}$ of $30 \%(\mathrm{~m} / \mathrm{v})$ trichloroacetic acid, $500 \mu \mathrm{L}$ of $0.8 \%(\mathrm{~m} / \mathrm{v})$ thiobarbituric acid and sufficient distilled water to complete the final volume of $2.0 \mathrm{~mL}$. After addition of each component, the sample was homogenized in a vortex following the above sequence. The tubes were heated in a boiling water bath for $30 \mathrm{~min}$, and after which time $5.0 \mathrm{~mL}$ of 1 -butanol was added to the mixture. The mixture was vortexed for $2 \mathrm{~min}$ and centrifuged at $5000 \mathrm{rpm}$ for $10 \mathrm{~min}$. The absorbance of the organic phase was measured in a spectrophotometer $(535 \mathrm{~nm})$. Results were expressed as $\mathrm{mg}$ of malonaldehyde (MDA) per kilogram of sample (mg MDA $/ \mathrm{kg}$ ). The analysis was carried out in triplicate.

\subsection{INSTRUMENTAL COLOR ANALYSIS}

The color measurements $(n=4)$ were obtained on the internal surface of the samples after a longitudinal cut, with a portable colorimeter (Chroma Meter CR-400/410, Konica Minolta Optics, Inc., Japan), calibrated with a white porcelain plate. The CIE scale $L^{*} C^{*} h$, consisting of the $L^{*}$ component, chroma $\left(C^{*}\right)$ and hue angle $\left(0^{\circ} \leq h^{\circ} \leq 360^{\circ}\right)$ was used. $L^{*}$ represents luminosity $\left(L^{*}=0\right.$ black and $L^{*}=100$ white). Chroma is an expression of color intensity or saturation. Hue angle is the observable color or tonality that changes in the angular direction representing the different existing colors. 
The project was approved (CAAE: 53646116.4.0000.5564) by the Human research ethics committee before conducting the sensory analysis. The trained panel consisted of six panelists who were trained as described in a previous study (MESSIAS et al., 2016). They evaluated color, odor, taste and overall impression of the products, using a scale ranging from 9 "very good quality", 7-8 "good quality", 5-6 "acceptable quality", 1-4 "poor or unacceptable quality", as described by Ozogul et al. (2010). These sensory attributes were chosen, as they indicate possible sensory changes due to lipid oxidation.

\subsection{MICROBIOLOGICAL ANALYSIS}

Total mesophilic bacteria (PCA media, $30^{\circ} \mathrm{C}, 48 \mathrm{~h}$ ) and Enterobacteriaceae(VRBG medium, $37^{\circ} \mathrm{C}, 24 \mathrm{~h}$ ) counts were performed according to American Public Health Association (APHA) methodologies described by Silva et al. (2010). The analyses were performed in duplicate.

\subsection{STATISTICAL ANALYSIS}

The effects of formulation (F), storage time (ST) and their interaction (F $\times$ ST) on the product parameters were analyzed by analysis of variance (ANOVA)to determine significant differences with $95 \%$ significance $(p<0.05)$. Results were expressed as mean \pm standard error of mean (SEM). If interaction F x ST was not significant, and an effect (F, ST) had significant difference, the results were also expressed as the mean of the factors ( $F$ or ST). The comparison of means was performed using the Tukey's test $(p<0.05)$, when statistical significance was found. Statistical analysis was carried out using Genes free software, version 1990.2017.61 (UFV, Brazil) (CRUZ, 2013).

\section{RESULTS AND DISCUSSIONS}

\subsection{CHEMICAL ANALYSES}

$\mathrm{pH}$ and peroxide values (PV) results for tilapia fish fingers with ginger extract (GE), rosemary extract $(\mathrm{RE})$ and control, during the frozen storage for 120 days are presented in TABLE 1. 
TABLE 1 - pH AND PEROXIDE VALUES (PV) OF TILAPIA FISH FINGERS CONTAINING GINGER EXTRACT (GE), ROSEMARY EXTRACT (RE), AND CONTROL DURING FROZEN STORAGE

\begin{tabular}{|c|c|c|c|c|c|c|c|}
\hline \multirow{2}{*}{$\begin{array}{l}\text { Storage time } \\
\text { (days) }\end{array}$} & \multicolumn{3}{|c|}{ Formulation (F) } & \multirow{2}{*}{ Mean } & \multicolumn{3}{|c|}{$p$ value } \\
\hline & GE & RE & Control & & F x ST & $\mathbf{F}$ & ST \\
\hline \multicolumn{5}{|l|}{$\mathrm{pH}$} & $0.063^{\text {ns }}$ & $1^{\text {ns }}$ & $0.141^{\mathrm{ns}}$ \\
\hline 0 & $6.3 \pm 0.1$ & $6.2 \pm 0.1$ & $6.1 \pm 0.1$ & \multirow{5}{*}{6.2} & & & \\
\hline 30 & $6.1 \pm 0.1$ & $6.1 \pm 0.1$ & $6.1 \pm 0.1$ & & & & \\
\hline 60 & $6.3 \pm 0.1$ & $6.1 \pm 0.1$ & $6.2 \pm 0.1$ & & & & \\
\hline 90 & $6.3 \pm 0.1$ & $6.5 \pm 0.1$ & $6.3 \pm 0.1$ & & & & \\
\hline 120 & $6.1 \pm 0.1$ & $6.1 \pm 0.2$ & $6.3 \pm 0.1$ & & & & \\
\hline \multicolumn{5}{|c|}{$P V\left(\right.$ meq $\mathrm{O}_{2} / \mathrm{kg}$ of fat $)$} & $0.168^{\mathrm{ns}}$ & $1^{\text {ns }}$ & 0.001 \\
\hline 0 & $0.7 \pm 0.1$ & $0.7 \pm 0.1$ & $0.7 \pm 0.1$ & $0.7^{\mathrm{b}}$ & & & \\
\hline 30 & $1.1 \pm 0.1$ & $1.0 \pm 0.1$ & $1.1 \pm 0.2$ & $1.1^{\mathrm{a}}$ & & & \\
\hline 60 & $0.7 \pm 0.1$ & $0.9 \pm 0.1$ & $0.9 \pm 0.1$ & $0.8^{b}$ & & & \\
\hline 90 & $0.7 \pm 0.1$ & $0.5 \pm 0.1$ & $0.7 \pm 0.1$ & $0.6^{b c}$ & & & \\
\hline 120 & $0.6 \pm 0.1$ & $0.4 \pm 0.2$ & $0.2 \pm 0.2$ & $0.4^{\mathrm{C}}$ & & & \\
\hline
\end{tabular}

$\mathrm{pH}$ was not affected by formulations $(\mathrm{F})$, storage times (ST) and interaction of the factors $\mathrm{F} \times \mathrm{ST}$. As a result,the mean value of $\mathrm{pH}$ wasreported in Table 1 and was approximately 6.2, which stands within the neutrality range. Post-mortem $\mathrm{pH}$ of fish ranges from 6.0 to 6.8 (KHALAFALLA; ALI; HASSAN, 2015), agreeing with the results found in this study. Additionally, Khalafalla; Ali; Hassan (2015) obtained similar pH values, ranging from 6.2 to 6.6 for tilapia fillets containing rosemary and thyme extracts during refrigerated storage for six days. The maximum $\mathrm{pH}$ considered acceptable for fish and fish products is 6.5 , and higher values can be attributed to the increase of volatile bases, such as ammonia, produced by endogenous or microbial enzymes (MANAT et al. al., 2005).

Regarding the PV results, F $\times$ ST was not significant, and no differences were observed among formulations during storage.Therefore, the natural extracts were not efficient in reducing the hydroperoxide formation, which is the primary product of the oxidative process. PV was only affected by storage time. For this reason, the mean values of PV for each storage time were reported in Table 1. It was observed a progressive decrease from 30 to 120 days. This is probably a result ofan increase in malonaldehyde (MDA)level, which is a byproduct from lipid oxidation.

In contrast,Ozogul et al. (2010) observed an increase in PV for sardines refrigerated for 20 days. Additionally, the sardine with rosemary extract presented a lower PV than the control. The results were also different from those found by Ozogul; Uçar (2013) with mackerel (Scomberjaponicus) fishburger with the addition of natural extracts. The authors obtained an increase in PV during the 8 months of frozen storage.

The TBARS methodology quantifies the MDA which is one of the main decomposition products of hydroperoxides that are formed during the oxidation process (OSAWA; DE FELÍCIO; GONÇALVES, 2005). This analysis was used to evaluate the effect of the extracts in controlling the lipid oxidation in tilapia fish fingers. There was interaction between formulation and storage time $(p<0.001)$. Results are shown in FIGURE 1. 


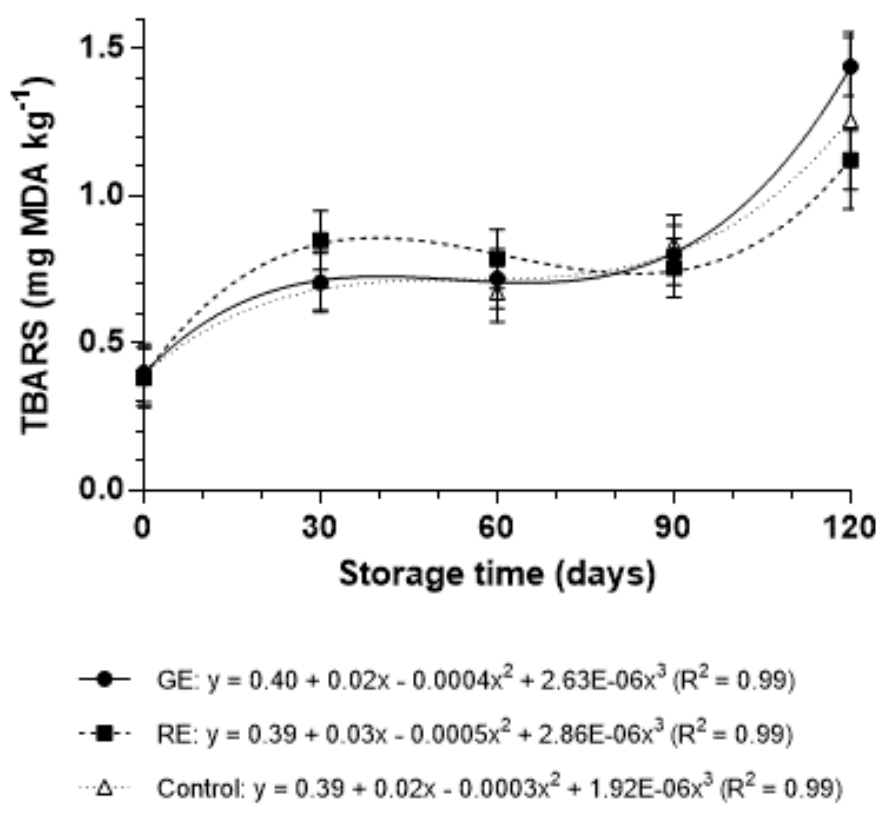

The levels of TBARS ranged from 0.4 to $1.4 \mathrm{mg} \mathrm{MDA} / \mathrm{kg}$ of sample. TBARS values followed a third order polynomialmodel and increased at the end of storage.Ozogul andUçar (2013) also found a progressive increase in the TBARSduring the frozen storage of mackerel fishburger containing plant extracts.

RE had the highest result at 30 days and reached the lowest TBARS value at 120 days. GE and the control had a similar behavior until 90 days. At the end of storage, GE had the highest value and the control reached a middle value between the two formulations with extracts. This result indicates that rosemary oily extract was more efficient to prevent lipid oxidation in the fish fingers during frozen storage. Similarly, Ozogul and Uçar (2013) concluded that rosemary extract presented antioxidant activity in mackerel fishburgers and reached lower values than the control.

Additionally, the product with ginger extract hada higher TBARS value than the control. This probably occurred due to the hydroalcoholicmethod used for this extract which could have also extracted metals which act as pro-oxidants in lipid oxidation reactions. Abbas et al. (2015) found high quantities of mineral elements, especially $\mathrm{Mg}$ and $\mathrm{Zn}$, in the hydroalcoholic extract of chicory (Cichoriumintybus L.) leaves.

\subsection{INSTRUMENTAL COLOR}

The instrumental color of the inner surface of the GE, RE and control fish fingers during storage time are shown in TABLE 2.All parameters had interaction between both factors $(\mathrm{F} \times \mathrm{ST})$. In addition, the formulations showed color changes throughout the frozen storage.

The brightness parameter $\left(L^{*}\right)$ ranged from 59.4 to 66.1 . $L^{*}$ showed no variation among formulations at the beginning of the study ("0 days"). GE presented lower $L^{*}$ from 60 to 
120 days, indicating a darker color than the other formulations. On the other hand, RE and control were slightly brighter (higher $L^{*}$ ) than GE.

The Hue angle (tonality) varied from 68.4 to $80.4^{\circ}$. Overall, the tonalities of all formulations increased during the storage time. GE and RE had Hue values near $75^{\circ}$ from 30 to 120 days, representing an orangish color,based on the $L^{*} C^{*} h$ color model. In addition, control had the highest values $\left(\sim 80^{\circ}\right)$ after 90 days which represents a yellowish color.

Chroma (color intensity) ranged from 13.7 to 17.7. Color intensity of GE and control did not vary, when comparing initial and final storage times. On the contrary, RE Chroma increased from $\sim 14$ to 16 . Additionally, control had the lowest color intensity at 120 days than RE and GE.

\subsection{SENSORY ANALYSIS}

A common way to evaluate fish freshness is using sensory analysis since important information is obtained in a simple and fast way (KHALAFALLA; ALI; HASSAN, 2015). A trained panel evaluated the attributes of color, odor, flavor and overall impression during frozen storage, which are presented in TABLE 3.

All formulations maintained the sensory color and odor during the study, with values near 8 and 7, respectively, which correspond to "good quality" in the scale. Formulations (F), storage times (ST) and the interaction of both factors did not affect these attributes. Consequently, the addition of extracts did not affect the fish finger color and odor during frozen storage.

Flavor and overall impression had interaction $F \times S T$. RE was not different from the control for both attributes, with averages close to 7, indicating that the two formulations maintained the sensory quality up to 120 days of storage. On the other hand, GE had the lowest scores in 90 and 120 days, corresponding to "bad or unacceptable quality". The trained panelists reported an undesirable change in the product due to the loss of ginger flavor and a presence of a rancid off-flavor. This result agrees with the highest TBARS value found for the formulation with ginger extract (FIGURE 1).

The present findings differed from previous studies. Khalafalla; Ali; Hassan (2015) found that tilapia fillets containing rosemary extract had lower scores than the control. The authors reported that the yellow coloration and rosemary strong odor negatively affected the sensory evaluation of the samples. ÇOBAN (2013) concluded that $1 \%$ ginger oil increased the shelf life of refrigerated fish fingers from Sardasardaand had a positive impact on sensory quality. 
TABLE 2 - INSTRUMENTAL COLOR OF TILAPIA FISH FINGERS CONTAINING GINGER EXTRACT (GE), ROSEMARY EXTRACT (RE), AND CONTROL DURING FROZEN STORAGE

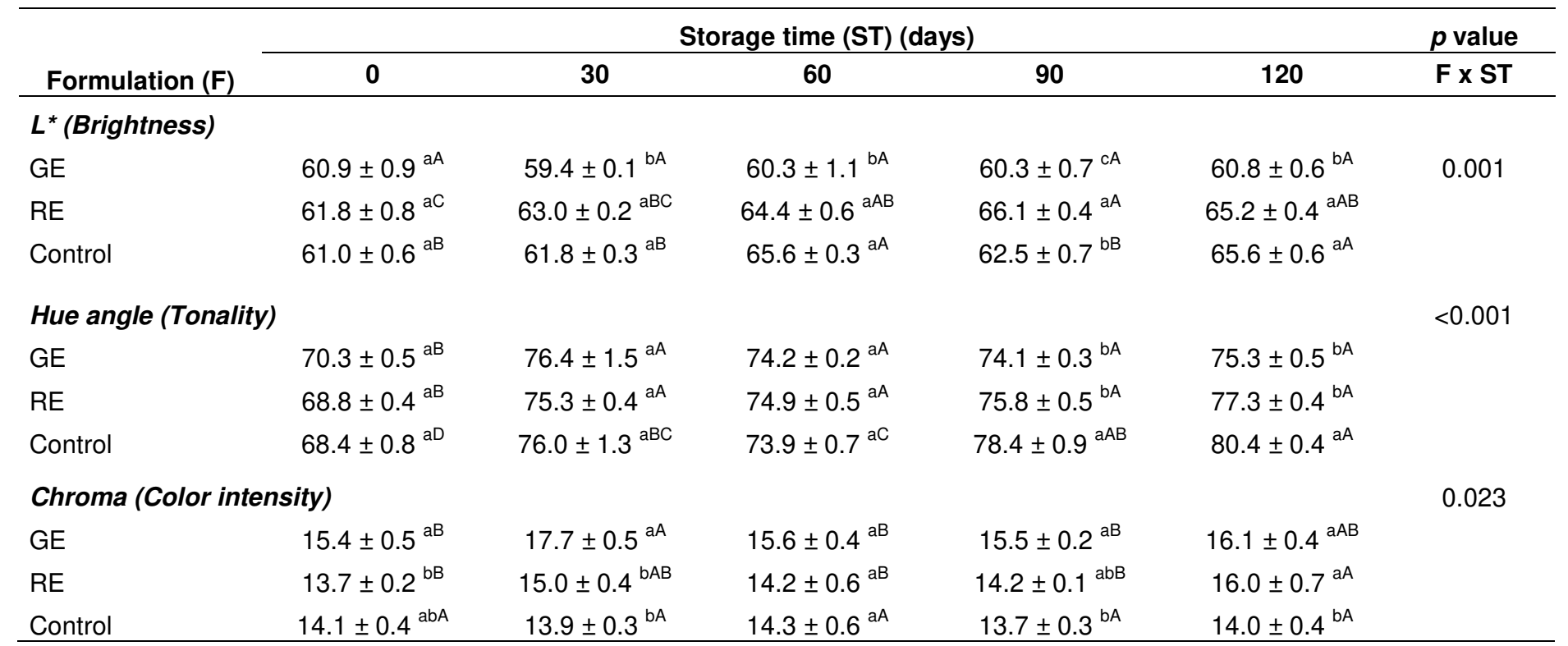

Results are expressed as mean \pm standard error of mean $(n=4$ replicates).

a-c Different and lowercase letters on the same column are significantly different by Tukey's test $(p<0.05)$

A-D Different and uppercase letters on the same line are significantly different by Tukey's test $(p<0.05)$. 
TABLE 3 - SENSORY EVALUATION OF TILAPIA FISH FINGERS, CONTAINING GINGER EXTRACT (GE), ROSEMARY EXTRACT (RE), AND CONTROL DURING FROZEN STORAGE

\begin{tabular}{|c|c|c|c|c|c|c|c|c|}
\hline \multirow[b]{2}{*}{ Formulation (F) } & \multicolumn{5}{|c|}{ Storage time (days) } & \multicolumn{3}{|c|}{ pvalue } \\
\hline & 0 & 30 & 60 & 90 & 120 & F x ST & $F$ & ST \\
\hline \multicolumn{9}{|l|}{ Color } \\
\hline GE & $8.2 \pm 0.4$ & $8.3 \pm 0.2$ & $8.0 \pm 0.5$ & $8.5 \pm 0.3$ & $8.3 \pm 0.3$ & $1^{\mathrm{ns}}$ & $0.087^{\text {ns }}$ & $0.296^{\mathrm{ns}}$ \\
\hline $\mathrm{RE}$ & $8.5 \pm 0.2$ & $8.5 \pm 0.2$ & $8.5 \pm 0.2$ & $8.5 \pm 0.3$ & $8.7 \pm 0.3$ & & & \\
\hline Control & $8.5 \pm 0.2$ & $8.7 \pm 0.2$ & $8.2 \pm 0.4$ & $8.2 \pm 0.3$ & $8.5 \pm 0.5$ & & & \\
\hline Odor & & & & & & $1^{\text {ns }}$ & $0.340^{\mathrm{ns}}$ & $0.237^{\text {ns }}$ \\
\hline GE & $8.3 \pm 0.4$ & $7.7 \pm 0.6$ & $6.8 \pm 0.5$ & $6.7 \pm 0.7$ & $6.8 \pm 0.7$ & & & \\
\hline $\mathrm{RE}$ & $8.0 \pm 0.4$ & $7.5 \pm 0.4$ & $7.5 \pm 0.4$ & $7.7 \pm 0.2$ & $7.5 \pm 0.6$ & & & \\
\hline Control & $7.7 \pm 0.5$ & $7.5 \pm 0.6$ & $7.3 \pm 0.6$ & $8.0 \pm 0.4$ & $7.5 \pm 0.6$ & & & \\
\hline Flavor & & & & & & 0.002 & - & - \\
\hline GE & $7.8 \pm 0.5^{\mathrm{aA}}$ & $7.0 \pm 0.4^{\mathrm{aA}}$ & $6.2 \pm 0.5^{\mathrm{aAB}}$ & $4.5 \pm 0.3^{\mathrm{bBC}}$ & $3.0 \pm 0.9^{b C}$ & & & \\
\hline $\mathrm{RE}$ & $8.5 \pm 0.3^{\mathrm{aA}}$ & $7.5 \pm 0.6^{\mathrm{aA}}$ & $7.7 \pm 0.5^{\mathrm{aA}}$ & $7.3 \pm 0.5^{\mathrm{aA}}$ & $7.2 \pm 0.5^{\mathrm{aA}}$ & & & \\
\hline Control & $7.7 \pm 0.4^{\mathrm{aA}}$ & $7.3 \pm 0.8^{\mathrm{aA}}$ & $6.7 \pm 0.7^{\mathrm{aA}}$ & $8.0 \pm 0.4^{\mathrm{aA}}$ & $6.7 \pm 0.5^{\mathrm{aA}}$ & & & \\
\hline Overall impression & & & & & & 0.007 & - & - \\
\hline GE & $8.2 \pm 0.4^{\mathrm{aA}}$ & $7.7 \pm 0.4^{\mathrm{aAB}}$ & $6.0 \pm 0.4^{\mathrm{bBC}}$ & $4.7 \pm 0.4^{b C}$ & $5.2 \pm 0.4^{\mathrm{bC}}$ & & & \\
\hline RE & $8.0 \pm 0.3^{\mathrm{aA}}$ & $7.7 \pm 0.9^{\mathrm{aA}}$ & $8.0 \pm 0.4^{\mathrm{aA}}$ & $7.3 \pm 0.5^{\mathrm{aA}}$ & $7.5 \pm 0.6^{\mathrm{aA}}$ & & & \\
\hline Control & $7.8 \pm 0.4^{\mathrm{aA}}$ & $8.2 \pm 0.5^{\mathrm{aA}}$ & $7.5 \pm 0.5^{\mathrm{abA}}$ & $7.7 \pm 0.4^{\mathrm{aA}}$ & $7.3 \pm 0.4^{\mathrm{aA}}$ & & & \\
\hline
\end{tabular}

Results are expressed as mean \pm standard error of mean ( $n=6$ replicates).

a-b Different and lowercase letters on the same column are significantly different by Tukey's test $(p<0.05)$

A-C Different and uppercase letters on the same line are significantly different by Tukey's test $(p<0.05)$. 


\subsection{MICROBIOLOGICAL ANALYSIS}

The microbiological quality of tilapia fish finger is important and necessary, since this product presents the possibility of microbial growth, because of its intrinsic properties (high water activity, $\mathrm{pH}$ near neutrality, etc.). The total counts of mesophilic bacteria and Enterobacteriaceaein the GE, RE and control formulations were carried out at the initial and final frozen storage time, as shown in Table 4. F $x$ ST interactions were significant for both analyses.

TABLE 4 - TOTAL MESOPHILIC AND ENTEROBACTERIACEAE COUNTS FOR TILAPIA FISH FINGERS CONTAINING GINGER EXTRACT (GE), ROSEMARY EXTRACT (RE) AND CONTROL DURING FROZEN STORAGE

\begin{tabular}{|c|c|c|c|}
\hline \multirow[b]{2}{*}{ Formulation (F) } & \multicolumn{2}{|c|}{ Storage time (ST) (days) } & \multirow{2}{*}{$\begin{array}{l}p \text { value } \\
F \times S T\end{array}$} \\
\hline & 0 & 120 & \\
\hline \multicolumn{4}{|l|}{ Mesophilic (CFU/g) } \\
\hline GE & $9.6 \times 10^{4} \pm 2.0 \times 10^{3 \mathrm{aA}}$ & $1.1 \times 10^{4} \pm 1.4 \times 10^{3 \mathrm{aB}}$ & 0.005 \\
\hline RE & $7.1 \times 10^{4} \pm 4.5 \times 10^{3 \mathrm{bA}}$ & $1.4 \times 10^{4} \pm 4.6 \times 10^{3 \mathrm{aB}}$ & \\
\hline Control & $5.5 \times 10^{4} \pm 6.2 \times 10^{3 \mathrm{cA}}$ & $8.0 \times 10^{3} \pm 9.2 \times 10^{2 \mathrm{aB}}$ & \\
\hline \multicolumn{3}{|c|}{ Enterobacteriacea (CFU/g) } & $<0.001$ \\
\hline GE & $5.9 \times 10^{3} \pm 4.3 \times 10^{2 \mathrm{aA}}$ & $1.3 \times 10^{3} \pm 2.5 \times 10^{1 \mathrm{aB}}$ & \\
\hline RE & $4.4 \times 10^{3} \pm 1.5 \times 10^{2 \mathrm{bA}}$ & $1.3 \times 10^{3} \pm 8.8 \times 10^{1 \mathrm{aB}}$ & \\
\hline Control & $1.5 \times 10^{3} \pm 3.7 \times 10^{2 \mathrm{cA}}$ & $1.3 \times 10^{3} \pm 9.8 \times 10^{1 \mathrm{aA}}$ & \\
\hline \multicolumn{4}{|c|}{$\begin{array}{l}\text { Results are expressed as mean } \pm \text { standard error of mean }(\mathrm{n}=2 \text { replicates). } \\
\text { CFU: Colony Forming Units. } \\
\text { a-c Different and lowercase letters on the same column are significantly different by Tukey's test } \\
(p<0.05) \text {. } \\
\text { A-B Different and uppercase letters on the same line are significantly different by Tukey's test } \\
(p<0.05) .\end{array}$} \\
\hline
\end{tabular}

The total mesophilic bacteria count in plates is a microbiological analysis used as a general indicator of the presence of bacteria in foods, since it does not differentiate bacteria types, providing overall information about product quality (SILVA et al., 2010). According to Marengoni et al. (2009), values higher than $10^{6} \mathrm{CFU} / \mathrm{g}$ indicates low fish freshness. The results reached a maximum of $9.6 \times 10^{4} \mathrm{CFU} / \mathrm{g}$, a value considered satisfactory. Additionally, the Enterobacteriaceaecount is used as an indicator of the process hygienic conditions (SILVA et al., 2010). The results obtained in this study were not higher than $5.9 \times 10^{3} \mathrm{CFU} / \mathrm{g}$.

The results were different among formulations at the beginning of the study. Control had lower microbial counts than GE and RE at " 0 days". In addition, reductionsin bacteria counts between 0 and 120 days were observed for all formulations, except for the Enterobacteriacea count of the control, which did not change signicantly.However, no difference was observed among formulations at the end of the storage period (120 days).

The extracts showed a small antibacterial effect againstmesophiles and enterobacteria in frozen tilapia fish fingers. This information agrees with the $\mathrm{pH}$ results (Table 1), which showed no difference between the beginning and end of the storage time, indicating that inhibition of microbial growth may have occurred during the frozen storage period. According to Colla; Hernandez (2003), there is no microbial growth at the temperature of- $18^{\circ} \mathrm{C}$ which is usually used to store frozen foods. 
Previous works concluded that rosemary (PORTE; GODOY, 2001) and ginger extracts (SUNILSON et al., 2009; SIVASOTHY et al., 2011) have antibacterial activity in vitro. However, these studies did not carry out the application of natural extracts to evaluate the antibacterial effect in food products. Khalafalla; Ali; Hassan (2015) verified that the rosemary extract presented weak antimicrobial activity in tilapia fillets stored under refrigeration.

\section{CONCLUSION}

The addition of natural extracts did not reduce the peroxide formation and microbial counts in the products. Rosemary extract decreased the malonaldehyde formation and maintained a good flavor at the end of the storage time. However, the addition of ginger extract negatively affected the fish fingers. The extraction method may affect the antioxidant and antimicrobial properties of the extracts.

\section{RESUMO}

\section{EFEITO DOS EXTRATOS DE GENGIBRE E DE ALECRIM COMO AGENTES ANTIOXIDANTE E ANTIBACTERIANO EM TIRINHA DE TILÁPIA}

Este trabalho teve como objetivo avaliar os efeitos antioxidante e antibacteriano de extratos comerciais de gengibre e de alecrim em tirinhas de tilápia durante armazenamento congelado. Três formulações de tirinhas utilizando carne mecanicamente separada (CMS) de tilápia foram produzidas, com adição de $2,5 \%$ de extrato hidroalcoólico de gengibre (GE), 2,5\% de extrato oleoso de alecrim (RE) e um controle. Análises de $\mathrm{pH}$, cor instrumental, valor de peróxidos (PV), determinação de substâncias reativas ao ácido tiobarbitúrico (TBARS), avaliação sensorial com painel treinado foram realizadas mensalmente durante 120 dias de armazenamento congelado.As contagens totais de mesófilos e de enterobactériasforam realizadas no início e final do armazenamento. $\mathrm{O} \mathrm{pH}$ permaneceu próximo de 6,0. GE apresentou coloração mais escura (menor $L^{*}$ ) no final do estudo. PV diminuiu com o tempo de armazenamento, mas não apresentou diferença entre as formulações. RE teve o menor valor de TBARS no tempo 120 dias. GE tornou-se de sabor inaceitável e apresentou o maior valor de TBARS no final da armazenagem congelada. Houve pouca redução das contagens bacterianas nos produtos com extratos. O extrato de alecrim foi mais eficiente em reduzir a oxidação lipídica nas tirinhas congeladas do que o extrato de gengibre.

PALAVRAS-CHAVE: EXTRATOS NATURAIS; ZINGIBER OFFICINALE; ROSMARINUS OFFICINALIS; OXIDAÇÃO LIPÍDICA; VIDA DE PRATELEIRA 


\section{REFERENCES}

ABBAS, Z. K.; SAGGU, S.; SAKERAN, M. I.; ZIDAN, N.; REHMAN, H.; ANSARI, A. A. Phytochemical, antioxidant and mineral composition of hydroalcoholic extract of chicory (Cichoriumintybus L.) leaves. Saudi Journal of Biological Sciences, v. 22, n. 3, p. 322-326,2015,

ANGIONI, A.; BARRA, A. CERETI, E.; BARILE, D.; COISSON, J. D.; ARLORIO, M.; DESSI, S.; CORONEO, V.; CABRAS, P. Chemical composition, plant genetic differences, antimicrobial and antifungal activity investigation of the essential oil of Rosmarinusofficinalis L. Journal of Agricultural and Food Chemistry, v. 52, n. 11, p. 3530-3535, 2004.

ARASHISAR, Ş.; HISAR, O.; KAYA, M.; YANIK, T. Effects of modified atmosphere and vacuum packaging on microbiological and chemical properties of rainbow trout (Oncorhynchus mykiss) fillets. International Journal of Food Microbiology, v. 97, n. 2, p. 209-214, 2004.

BLIGH, E.G.; DYER, W.J. A rapid method of total lipid extraction and purification.Canadian Journal of Biochemistry and Physiology, v. 37, p. 911-917, 1959.

BOtTERWECK, A. A., VERHAGEN, H., GOLDBOHM, R. A., KLEINJANS, J., \& VAN DEN BRANDT, P. A. Intake of butylated hydroxyanisole and butylated hydroxytoluene and stomach cancer risk: Results from analyses in the Netherlands cohort study. Food and Chemical Toxicology, v. 38, n. 7, p. $599-605,2000$.

CAROCHO, M.; MORALES, P.; FERREIRA, I. C. F. R. Antioxidants: Reviewing the chemistry, food applications, legislation and role as preservatives. Trends in Food Science and Technology, v. 71, p. 107-120, 2018.

ÇOBAN, O.E. Effect of ginger oil on the sensory and chemical changes of fish finger (Sardasarda, heckel 1843) during refrigerated storage. International Food Research Journal, v. 20, n. 4, p. 1575-1578, 2013.

COLLA, L. M.; HERNANDEZ, C. P. Congelamento e Descongelamento: sua influência sobre os alimentos. Vetor, Rio Grande do Sul, v. 13, p. 53-66, 2003.

CRUZ, C.D. Gens - a software package for analysis in experimental statistics and quantitative genetics. ActaScientiarum, v.35, n.3, p.271-276, 2013.

FAO. 2011. Global food losses and food waste - Extent, causes and prevention. Rome: Food and Agriculture Organization of the United Nations (FAO), 2011.

FRANKEL, E.N. Food antioxidants and phytochemicals: present and future perspectives. European Journal of Lipid Science and Technology, v. 101, n. 12, p. 450-455. 1999.

HASSOUN, A.; ÇOBAN, O.E. Essential oils for antimicrobial and antioxidant applications in fish and other seafood products. Trends in Food Science \& Technology, v. 68, p. 26-36, 2017.

INSTITUTO ADOLFO LUTZ (IAL). Métodos Físico-Químicos para Análise de

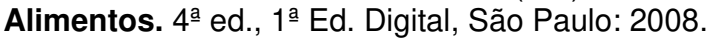

KHALAFALLA, F. A.; ALI, F. H. M.; HASSAN, A. H. A. Quality improvement and shelf-life extension of refrigerated Nile tilapia (Oreochromisniloticus) fillets using natural herbs. Beni-Suef University Journal of Basic and Applied Sciences, v. 4, n. 1, p. 33-40, 2015.

MARENGONI, N. G.; POZZA, M. S. S.; BRAGA, G. C.; LAZZERI, D. B.; CASTILHA, L. D.; BUENO, G. W.; PASQUETTI, T. J.; POLESE, C. Caracterização microbiológica, sensorial e centesimal de fishburgers de carne de tilápia mecanicamente separada. Revista Brasileira de Saúde e Produção Animal, v. 10, n. 1, p. 168-176, 2009.

MANAT, C.; SOOTTAWAT, B.; WONNOP, V.; CAMERON, F. Changes of pigments and colour in sardine (Sardinellagibbosa) and mackerel (Rastrelligerkanagurta) muscle during iced storage. Food Chemistry, v. 93, p. 607-617, 2005.

MESOMO, M. C.; SCHEER, A. P.; PEREZ, E.; NDIAYE, P. M.; CORAZZA, M. L. Ginger (Zingiberofficinale R.) extracts obtained using supercritical $\mathrm{CO}_{2}$ and compressed propane: Kinetics and antioxidant activity evaluation. Journal of Supercritical Fluids, v. 71, p. 102-109, 2012. 
MESOMO, M. C.; CORAZZA, M. L.; NDIAYE, P. M.; DALLA SANTA, O. R.; CARDOZO, L.; SCHEER, A. P. Supercritical $\mathrm{CO}_{2}$ extracts and essential oil of ginger (Zingiber officinale R.): Chemical composition and antibacterial activity. Journal of Supercritical Fluids, v. 80, p. 44-49, 2013.

MESSIAS, C. R.; KONOPKA, D. N.; BIASSI, D. C.; BATISTA, R. V.; QUAST, E.; BAINY, E. M.; POLISELI-SCOPEL, F. H. Treinamento e caracterização sensorial de formulações de fishburguer elaboradas à base de subprodutos da filetagem de tilápia. Brazilian Journal of Food ResearchREBRAPA, v.7, p.125 - 142, 2016.

MISHARINA, T.A.; TERENINA, M.B.; KRIKUNOVA, N.I. Antioxidant properties of essential oils. Applied Biochemistry and Microbiology, v. 45, n. 6, p. 642-647, 2009.

MUZZOLON, E.; BIASSI, D. C.; KONOPKA, D.; OLIVEIRA, J. de; POLISELI-SCOPEL, F. H.; BAINY, E. M.Fishburger processing using tilapia filleting byproducts: Physicochemical characterization, freezing analysis and shelf life evaluation. Brazilian Journal of Food Research - REBRAPA, v. 9, n. 1 de 2018 (In press).

OSAWA, A, C. C.; FELÍCIO, P. E.; GONÇALVES, L. A. G. Teste de TBA aplicado a carnes e derivados: métodos tradicionais, modificados e alternativos. Química Nova, São Paulo, v. 28, n. 4, p. 655-663, 2005.

OZOGUL, Y.;AYAS, D.; YAZGAN, H.; OZOGUL, F.; BOGA, E. K.; OZYURT, G. The capability of rosemary extract in preventing oxidation of fish lipid. International Journal of Food Science and Technology, n. 45, p. 1717-1723, 2010.

OZOGUL, Y.; UÇAR, Y. The Effects of Natural Extracts on the Quality Changes of Frozen Chub Mackerel (Scomberjaponicus) Burgers. Food and Bioprocess Technology, v. 6, n. 6, p. 15501560, 2013.

PISOSCHI, A. M.; POP, A.; GEORGESCU, C.; TURCUS, V.; OLAH, N. K.; MATHE, E. An overview of natural antimicrobials role in food. European Journal of Medicinal Chemistry, v. 143, p. 922935, 2018.

POLONIO, M. L. T.; PERES, F. Food additive intake and health effects: public health challenges in Brazil. Cadernos de Saúde Pública, v. 25, n. 8, p. 1653-1666, 2009.

PORTE, A.; GODOY, R.L.O. Alecrim (RosmarinusofficinalisL.): propriedades antimicrobianas e químicas do óleo essencial. Boletim Centro de Pesquisa de Processamento de Alimentos, v. 19, n. 2, p. 193-210, 2001.

SANTOYO, S.; CAVERO S.; JAIME, L.; IBAÑEZ, E.; SEÑORÁNS, F.J.; REGLERO, G. Chemical composition and antimicrobial activity of Rosmarinusofficinalis $L$. essential oil obtained via supercritical fluid extraction. Journal of Food Protection, v. 68, n. 4, p. 790-5, 2005.

SILVA, N.; JUNQUEIRA, V. C. A.; SILVEIRA, N. F. A.; TANIWAKI, M. H.; SANTOS, R. F. S.; GOMES, R. A. R.; OKAZAKI, M. M. Manual de métodos de análise microbiológica de alimentos e água. 4. ed. São Paulo, SP: Varela, 2010, 624 p.

SIVASOTHY, Y. CHONG, W. K.; HAMID, A.; ELDEEN, I. M.; SULAIMAN, S. F.; AWANG, K. Essential oils of Zingiberofficinale var. rubrumTheilade and their antibacterial activities. Food Chemistry, n. 124, p. 514-517, 2011.

SOARES, K. M. P.; GONÇALVES, A. A.; SOUZA, L. B. Qualidade microbiológica de filés de tilápia do Nilo (Oreochromisniloticus) durante o armazenamento em gelo. Ciência Rural, Santa Maria, v. 44, n. 12, p. 2273 - 2278, 2014.

SUNILSON, J. A. J.; SURAJ, R.; REJITHA, G.; ANANDARAJAGOPA, K. In vitro antibacterial evaluation of Zingiberofficinale, Curcuma longa and Alpinia galangal extracts as natural foods preservatives. American Journal of Food Technology, v. 4, n. 5, p. 192-200, 2009. 